\title{
Article history: $\quad$ Received: 20.04.2016 \\ The application of value stream mapping method for identifying basic drawbacks and reducing duration of information process in a company
}

\author{
Justyna Żywiołek \\ Institute of Production Engineering, Częstochowa University of Technology, Armii Krajowej 19B, Poland, e-mail: j.zywiolek@gmail.com

\begin{abstract}
The article presents the method of mapping the value stream and the stages of the creation of value stream mapping to identify the fundamental flaws of the process flow of information and shortening the duration of the process of the information in the audited company. The audited one large manufacturing company. Quantity of information which is reaching the company and process, is so large that it needs to implement methods to improve their flow. The research involved mapping the information when selected information flows.
\end{abstract}

Key words - Value Stream Mapping, Information process mapping, identification of drawbacks of information processes, reduction of time of information processes.

\section{Introduction}

The basis of the changes in the organization is aware of information which form the basis of these changes, their rationale and tools used to make changes and analysis of information process, to assess whether the changes were carried out effectively and efficiently.

Information is the essential intangible resource of the organization which can be directly transposed to its value (Business Value - BV) (SZYMONIK A. 2010). In literature there are multiple definitions of information depending on the field it operates in. As J. Oleński observes, the practitioners who design information processes have defined information as the kind of re- source that enables to increase knowledge about us and the surrounding (OLEŃSKI J. 2006).

Information and its circulation in the company is one of the elements that influences safety in the company. The efficient monitoring of information flows in companies can be conducted due to their organization in a proper way and mapping of information processes. Properly organized activities within value stream mapping are performed at the adequate levels of management.

\section{Information in the company}

Information as one of the most important resources, companies can also be analyzed by which 
improves the functioning of the company. The analyzed company belongs to the group of manufacturing companies classified as large. The number of its processed information is depicted in Fig. 1.

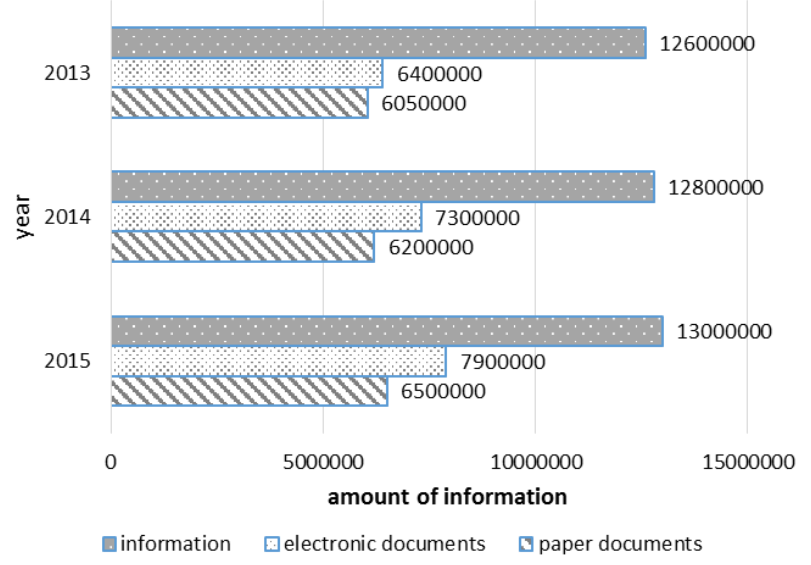

Fig. 1. Amount of processed information in the analyzed Source: author's elaboration company

It can be observed that in the analyzed company the following years the amount of processed information is increasing. The number of electric documents has grown significantly in the analyzed period, as well. The awareness that there is necessity to apply value stream mapping requires learning the sort of processed information (Fig. 2).

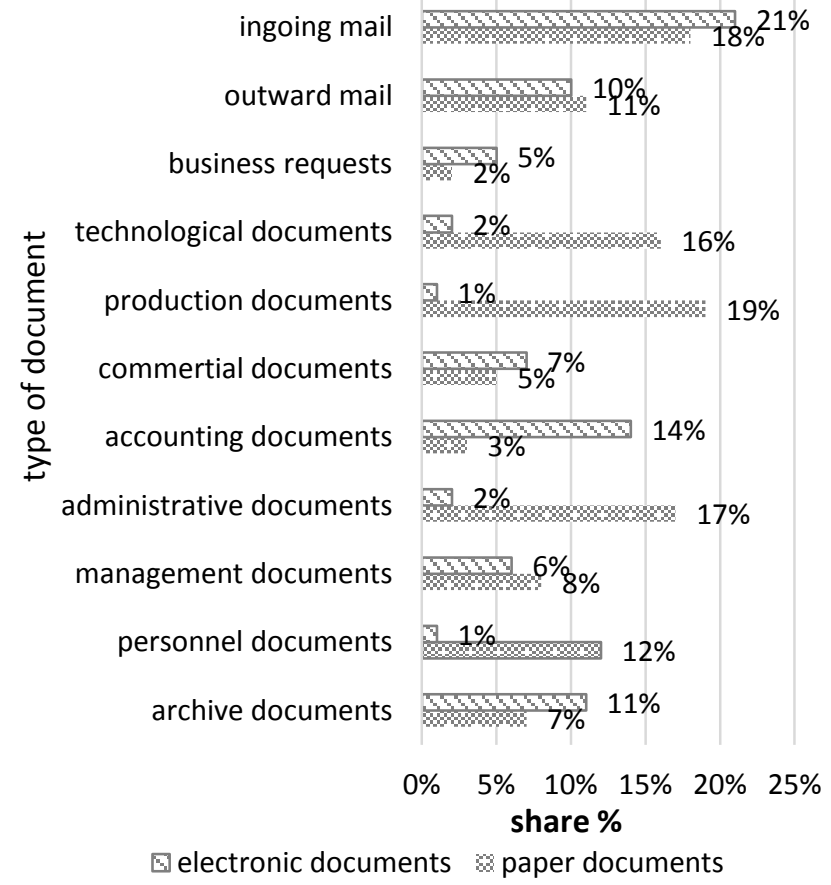

Fig. 2. Type of processed information in 2015 with the form of recording

Source: author's elaboration
The increasing number of documents is processed in the analyzed company. It becomes particularly difficult to make proper circulations of documents when one copes with two possibilities of processing documents. The process of preparing correct circulations of documents is time-consuming. However, it facilitates access to the given document for employees that it is addressed to. Creating correct flows of documents and information can be facilitated by the virtue of Value Stream Mapping.

\section{Value Stream Mapping Method}

Value Stream Mapping tool was introduced in Toyota Production System. The majority of initiatives of lean manufacturing begin with implementing this tool. It becomes the formal way of analyzing methods of production and identifying tasks or areas and flowing information, which creates value added. VSM (Value Stream Mapping) is a popular technique that is used for pointing the elements of processes in the company in order to distinguish the activities that add value and the ones that do not have an impact on value. Then, the flow of information and materials, connections between clients and suppliers and the company, as well as internal processes are presented in a clear and transparent way. By identification of these operations on the deliberately prepared map of processes, the points which need improvement can be easily noticed (HoBBS D, 2011). Value Stream Mapping is based on creating detailed map of processes of the company. In order to map processes a team of employees should be collected and the particular operations that take place during production of the given item need to be analyzed. Subsequently, the flow of good and information should be marked, duration of technological operations and transport, as well as the most important information concerning contracts with customers and suppliers need to be given. After preparing the map, the team has to analyze it for purposes of identifying the point that could be improved. If one is found, brainstorm is made in order to choose the most optimal variant of justifying solution (HOBBS D, 2011). Value Stream Mapping for the exemplary process is shown in Fig. 3. 


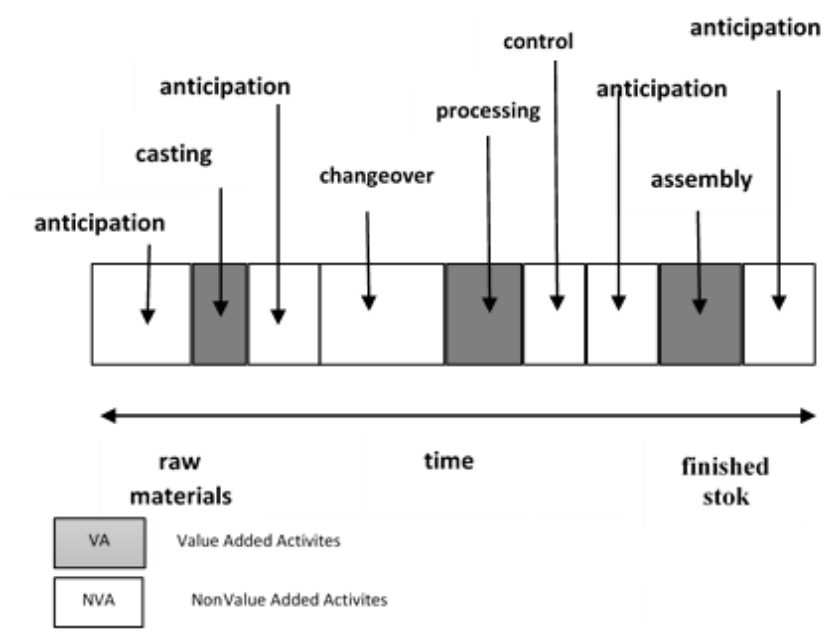

Fig. 3. Flow of product in manufacturing process with selecting Value-Added and Non Value Added Activities

Source: LIKER J.K. 2004

It can be inferred that Value Stream Mapping may bring positive changes in the company. The effectiveness of this method depends on qualifications of the given employees, who are responsible for analyzing the processes, finding the points that are exposed to changes and applying proper tools for their implementation. Value Stream defines all elements of the process which are indispensable for generation of products and services. Waste in the process prolongs production cycle and directly makes the cost of production increasing. The presented approach differs considerably from improving the activity which is oriented towards reducing time within the activities acknowledged as the ones that add value. The above-mentioned approach is presented in Fig. 4.

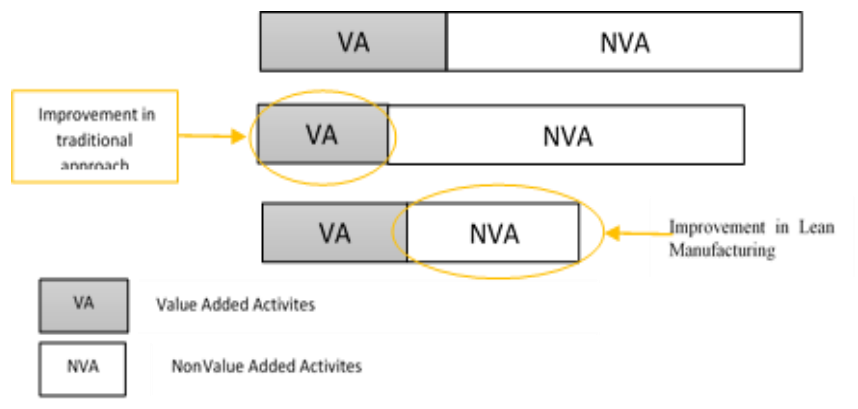

Fig. 4. Schematic comparison of traditional approach to improvement and improvement based on elimination of Non Value Added Activities

SOurce: LIKER J.K. 2004

What becomes the essence of the presented comparison is the indication that by improving the aspects concerned with efficiency along with neglecting the significance of flow in the entire system, it makes manufacturing transition time prolong. (ZIÓŁKOWSKI H. 2014).

The most important benefits that become the result of applying VSM are as following: (PASTERNAK K, 2004):

- Depicting information flow and resources of the company, which enables the identification of waste and reduction of costs,

- Integration of activities in the company along with the needs of customers, maximization of value added for recipient,

- Reduction of flow time of the product or service by the company even up to $80 \%$,

- Improvement of liquidity of the company,

- Improvement of work organization in the company.

VSM is the tool used universally, most frequently in manufacturing business, but also in logistics, information technology, medical service and many other branches of economy. The implementation of mapping becomes an arduous process and one needs to supply with collection of information about production and information flows in the company.

\section{Value Stream Mapping in the ana- lyzed company}

The recognition of information flows has been the first activity serving the implementation of Value Stream Mapping, which has enabled to prepare tools that reduce waste and anticipation time. In order to improve the processes in the analyzed company Value Stream Mapping for information flows during acceptance of external invoice, circulation of the document in the company and its archiving (Fig. 5), as well as information value stream flows during the assembly of elements that serve the construction of a garden chair, have been prepared (Fig. 6). 


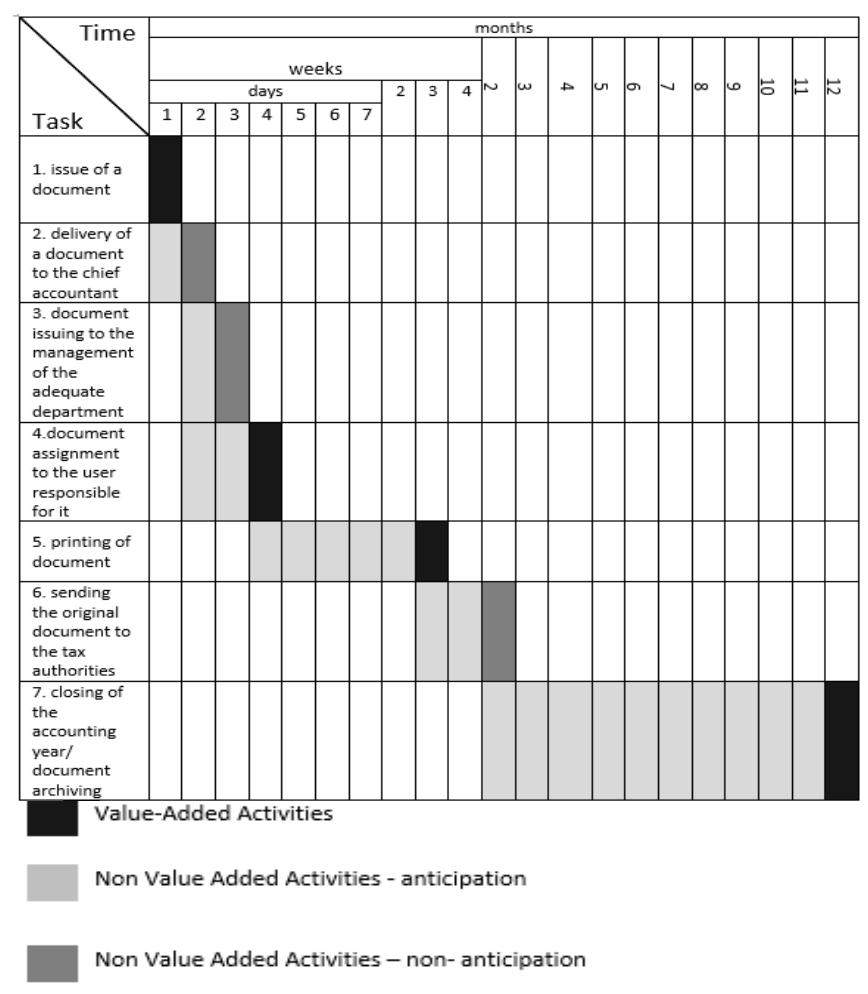

Fig 5. Information Value Stream Mapping for a tax return Source: author's elaboration

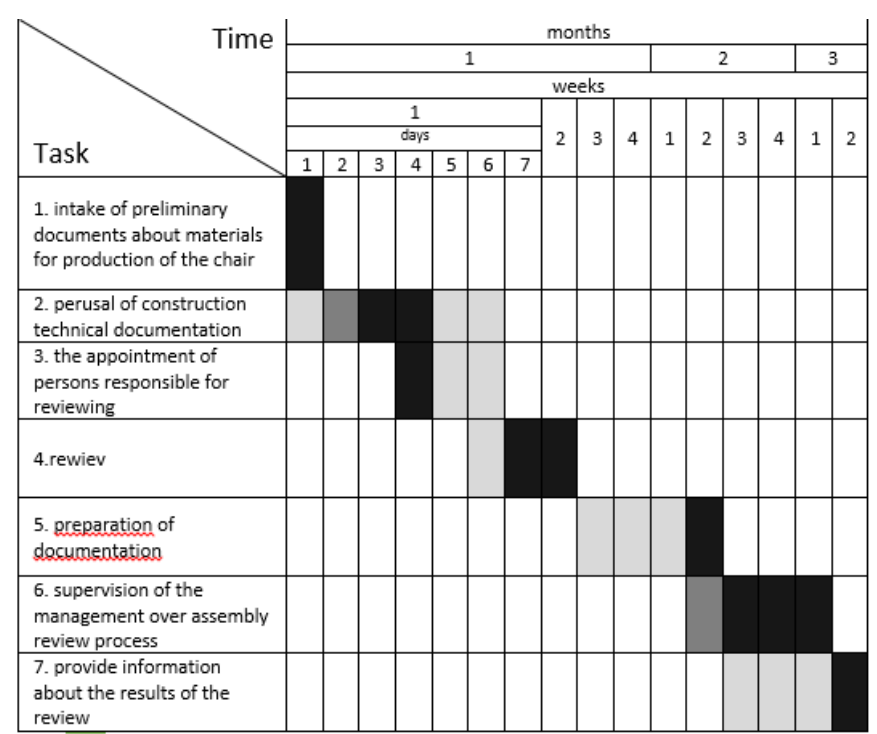

Fig. 6. Value stream mapping information for the preparation of the review machinery

Source: author's elaboration

\section{Summary and conclusions}

Information Value Stream Mapping applied in the analyzed company allowed for effective use of information resources and reduction of waste. Speed of access to information and awareness concerning time of particular operations have contributed to improvement of quality of the performed tasks and reduction of service time of the particular task. Information Value Stream Mapping enables to create and modify the respective processes that take place in the company. It facilitates the work of management within control over feasibility of tasks. Moreover, the conflicts concerned with division of tasks for employees do not occur. Research conducted in the company were used to increase the efficiency of information processes and to bridge the places of occurrence information only to sites that add the value of the informative process.

\section{Literature}

1. BRAL W. Obieg $i$ ochrona dokumentów, Difin, Warszawa, 2008.

2. ŁUNARSKI J. Systemy zarządzania bezpieczeństwem w przedsiębiorstwie, Oficyna Wydawnicza Politechniki Rzeszowskiej, Rzeszów, 2009.

3. SZYMONIK A., Narzędzia ułatwiajace pozyskiwanie informacji $i$ wiedzy na potrzeby zarzadzania bezpieczeństwem, Infrastruktura bezpieczeństwa publicznego. Ogólnokrajowe $i$ lokalne wyzwania cywilizacyjne. Ciekanowski Z. (red.), Wyd. Wyższa Szkoła Zarządzania i Prawa im. Heleny Chodkowskiej w Warszawie, Warszawa, 2010.

4. OLEŃSKI J., Infrastruktura informacyjna państwa w globalnej gospodarce, Wyd. Uniwersytetu Warszawskiego, Warszawa, 2006.

5. HoBBS D. Applied Lean Business Transformation. J. Ross Publishing Inc., Ft. Lauderdale, FL 2011.

6. PASTERNAK K. Zarys zarzadzania produkcja. PWE, Warszawa 2005.

7. ZIÓŁKOWSKI H. Koncepcja Lean Manufacturing. Projektowanie Procesów Produkcyjnych. Łódź 2014

8. BRAL W., Obieg $i$ ochrona dokumentów, Difin, Warszawa, 2008.

9. ŁUCZAK J., TYBULSKI M., Systemowe zarzadzanie bezpieczeństwem informacji ISO/IEC 27001, Wyd. Uniwersytetu Ekonomicznego w Poznaniu, 2010, Poznań.

10. Cygan T., Podręcznik administratora bezpieczeństwa informacji, Presscom, Wrocław, 2011.

11. ŁUNARSKI J., Systemy zarządzania bezpieczeństwem $w$ przedsiębiorstwie, Rzeszów, 2009.

12. ŻYWIOŁEK J., STANIEWSKA E., Informacje $w$ przedsiębiorstwie - zarzadzanie obiegiem dokumentów, Informacje $i$ marketing $w$ działalności organizacji (red.) Howaniec H., Szewczyk I., Waszkielewicz W., Wyd. ATH, Bielsko Biała 2013. 